\title{
Promazine Complexes of Transition Metal Ions: Synthesis
}

\author{
Dayakar R. Gouru ${ }^{1}$, Vishnuvardhan R. Thakkalapally ${ }^{1}$, Tarab J. Ahmad ${ }^{1}$, S. Ananda ${ }^{2}$, \\ Netkal M. Made Gowda ${ }^{1, *}$ \\ ${ }^{1}$ Department of Chemistry, Western Illinois University, One University Circle, Macomb, 61455, USA \\ ${ }^{2}$ Department of Studies in Chemistry, University of Mysore, Manasagangothri, Mysore, 570006, India
}

\begin{abstract}
Psychotherapeutic, antiemetic, and antihistamine activities are exhibited by some of the N-alkylaminophenothiazine derivatives including promazine $(\mathrm{P})$. The $\mathrm{N}$-alkylamine side chain is implicated in the aforementioned pharmacological activities. Several promazine (P. $\mathrm{HCl}$ or $\mathrm{C}_{17} \mathrm{H}_{20} \mathrm{~N}_{2} \mathrm{~S}$. HCl) complexes of the transition metal ions, $\mathrm{Zn}(\mathrm{II}), \mathrm{Cd}(\mathrm{II})$ and $\mathrm{Hg}(\mathrm{II})$, have been synthesized. The complexes have been characterized by their elemental analysis, molar conductivity, magnetic susceptibility, UV-Visible, IR and ${ }^{1} \mathrm{H}-\mathrm{NMR}$ data. The molecular formulations of the new mononuclear complexes have been proposed. These complexes behave in DMF solutions as 1:1 electrolytes. Molecular structures have been proposed showing a square pyramidal environment around each metal center with an $\mathrm{sp}^{3} \mathrm{~d}$ hybridization for the five-coordinate complexes, $\left[\mathrm{ZnBr}\left(\mathrm{C}_{17} \mathrm{H}_{20} \mathrm{~N}_{2} \mathrm{~S} . \mathrm{HCl}\right)_{2}\right] \mathrm{Br},\left[\mathrm{CdBr}\left(\mathrm{C}_{17} \mathrm{H}_{20} \mathrm{~N}_{2} \mathrm{~S} . \mathrm{HCl}\right)_{2}\right] \mathrm{Br}$, [CdI $\left.\left(\mathrm{C}_{17} \mathrm{H}_{20} \mathrm{~N}_{2} \mathrm{~S} . \mathrm{HCl}\right)_{2}\right] \mathrm{I} \cdot \mathrm{H}_{2} \mathrm{O}$ and $\left[\mathrm{HgBr}\left(\left(\mathrm{C}_{17} \mathrm{H}_{20} \mathrm{~N}_{2} \mathrm{~S}\right.\right.\right.$. $\left.\mathrm{HCl})_{2}\right] \mathrm{Br}$.
\end{abstract}

Keywords Promazine, Metal Complexes, Synthesis, Characterization, Elemental and Spectroscopic Analyses

\section{Introduction}

N-Alkylphenothiazines (NAPTZs) are biologically active heterocyclic compounds with the general structure shown in Fig.1. Their research was initially stimulated by the discovery of the anthelmintic action of $\mathrm{N}$-substituted and C-substituted derivatives ${ }^{1}$. However, in recent years coordinating behavior of NAPTZs has gained much importance due to their extensive applications in industry, medicine, and chemical analysis ${ }^{2}$. Some of the NAPTZ ligands including promazine $(\mathrm{P})$ are used as psychotherapeutic, antiemetic, and antihistamine drugs. The $\mathrm{N}$-alkylamine side chain is considered to be responsible for the aforesaid pharmacological activities[1-3].

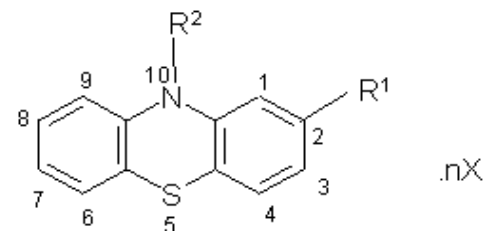

Figure 1. General molecular structure of phenothiazine derivatives<smiles>CN(C)CCCN1c2ccccc2Sc2ccccc21</smiles>

Figure 2. Molecular structure of promazine

* Corresponding author:

gn-made@wiu.edu (Netkal M. Made Gowda)

Published online at http://journal.sapub.org/chemistry

Copyright (C) 2011 Scientific \& Academic Publishing. All Rights Reserved
Among the NAPTZ derivatives, promazine (trade name Sparine), 10-(3-dimethylaminopropyl)phenothiazine, belongs to the aliphatic phenothiazine class of antipsychotics. It is also used as moderate sedative. The structure of promazine is shown in Fig. 2.

Previously, some studies of transition metal-NAPTZ complexes have been reported by several workers[4-16]. Keshavan and co-workers[4-7] have synthesized and characterized compounds of selected NAPTZs with molybdenum(IV), tungsten(IV), ruthenium(II/III) and copper(II) ions. Keshavan and Janardhan[7], and Gowda and Jayarama [8] have reported mononuclear copper(II) and zinc(II) complexes of NAPTZs. Kroener et al.[9] have studied the X-ray crystal structures of some cis- and trans-bis (2,2'-bipyridine) -bis (phenothiazine-S) ruthenium(II) hexaflurophosphates. Made Gowda et al. have previously studied the synthesis and characterization of some coordination compounds of NAPTZs with rhodium (II/III), rhenium (VII), iridium (III /IV), molybdenum (IV/V), zinc(II), palladium (II) and mercury (II)[10-16]. Chaitanya Lakshmi et al have reported the synthesis and free-radical scavenging activities of transition metal (II)-pyridoxine complexes[17-19]. In this report, the synthesis and characterization of the transition metal complexes with $\mathrm{P} . \mathrm{HCl}$ as the main ligand is presented.

\section{Experimental}

\subsection{Materials}

Metal salts, zinc bromide, cadmium bromide, cadmium iodide and mercuric bromide, and the ligand, promazine hydrochloride ( $\mathrm{P} \cdot \mathrm{HCl} ; 99 \%$ purity) were obtained from $\mathrm{Al}-$ 
drich/Sigma Chemical Company, USA. All organic solvents such as methanol, ethanol, diethyl ether, dimethyl sulfoxide, dimethyl formamide and DMSO- $\mathrm{d}_{6}$ (Cambridge isotope laboratories Inc.) were of ACS reagent grade and were used without further purification. Double distilled water was used in all preparations.

\subsection{Physical Measurements}

Elemental analyses of complexes were performed by Microanalysis Laboratory, University of Illinois, UrbanaChampaign, IL. Molar conductance was determined with the Conductance-Resistance meter. Melting points were determined on a Melt-Temp apparatus from Laboratory Devices, Cambridge, MA. Shimadzu UV1601 spectrophotometer was used to measure uv-visible spectra and absorbances of analyte solutions. The infrared spectra were recorded using potassium bromide discs on a Shimadzu FTIR 8400 spectrometer. ${ }^{1} \mathrm{H}-\mathrm{NMR}$ spectra were recorded on a JEOL-300 MHz FT-NMR spectrometer in DMSO-d d $_{6}$. Mass magnetic susceptibilities of the complexes were measured at room temperature with a Johnson Matthey magnetic susceptibility balance, which uses $\mathrm{HgCo}(\mathrm{SCN})_{4}$ as a calibrant.

\subsection{General Synthesis of Complexes}

A known concentration of the transition metal salt ( $\mathrm{x}$ mmol) $\left(\mathrm{ZnBr}_{2}, \mathrm{CdBr}_{2}, \mathrm{CdI}_{2}\right.$ and $\left.\mathrm{HgBr}_{2}\right)$ in a minimum volume of $\mathrm{MeOH}$ was slowly added with stirring to a concentrated methanolic solution of P.HCl (2x mmol) and refluxed overnight. Each reaction mixture cooled overnight at $0^{\circ} \mathrm{C}$ precipitated a product, which was isolated by suction filtration through a medium-glass fritted funnel. The product was washed with small amounts of cold water first followed by $\mathrm{MeOH}$, air-dried, and dried in vacuo over anhydrous $\mathrm{CaSO}_{4}$ in a desiccator. Each crude product was recrystallized twice from a hot saturated solution in $\mathrm{MeOH}$ and dried as before. The yield was determined.

The following general equation represents the stoichiometric reaction involved in the formation of complexes:

$$
\mathrm{MX}_{2}+2 \mathrm{P} . \mathrm{HCl} \stackrel{\mathrm{MeOH} / \mathrm{H}_{2} \mathrm{O}}{\longrightarrow} \mathrm{MX}_{2}(\mathrm{CP} . \mathrm{HCl})_{2}
$$

Where $\mathrm{M}=\mathrm{Zn}(\mathrm{II}), \mathrm{Cu}(\mathrm{II})$ or $\mathrm{Hg}(\mathrm{II})$ and $\mathrm{X}$ is $\mathrm{Br}^{-}$or $\mathrm{I}^{-}$.

\section{Results and Discussion}

The molecular formulations and structures of the complexes were determined on the basis of elemental analysis, molar conductance, UV-Vis, IR, and NMR data. The complexes are slightly soluble in common polar solvents such as $\mathrm{MeOH}$ and $\mathrm{EtOH}$ and readily soluble in acetone, acetonitrile, nitromethane, DMF, and DMSO $(0.4 \mathrm{~g}-2.0 \mathrm{~g}$ per $100 \mathrm{~mL}$ ). All products except $\mathrm{Zn}(\mathrm{II})$ complex are insoluble in water.

The physical properties of the new metal-P.HCl complexes are presented in Table 1. Complexes are colored, crystalline/microcrystalline, and relatively stable above room temperature as indicated by their melting point ranges with percent yields ranging from 82 to 93 .

Table 1. Physical properties of metal-P.HCl complexes

\begin{tabular}{|c|c|c|c|c|c|}
\hline Complex & $\begin{array}{c}\text { Melting } \\
\text { point }\left({ }^{\circ} \mathrm{C}\right)\end{array}$ & $\begin{array}{c}\text { Molar conductance } \\
\left(\mathrm{ohm}^{-1} \mathrm{~cm}^{2} \mathrm{~mol}^{-1}\right) \text { in nitromethane }\end{array}$ & $\begin{array}{c}\text { Mass magnetic } \\
\text { Susceptibility }\left(10^{-6} \mathrm{cgs}\right)\end{array}$ & Color & $\%$ Yield \\
\hline $\mathrm{ZnBr}_{2}(\mathrm{P} . \mathrm{HCl})_{2}$ & $90-110$ & $93.24(1: 1)($ electrolyte $)$ & -0.16 (diamagnetic) & colorless & 93.3 \\
\hline $\mathrm{CdBr}_{2}(\mathrm{P} . \mathrm{HCl})_{2}$ & $138-145$ & $114.0(1: 1)$ (electrolyte) & -0.38 (diamagnetic) & colorless & 87.1 \\
\hline $\mathrm{CdI}_{2}(\mathrm{P} . \mathrm{HCl})_{2}$ & $118-130$ & $93.24(1: 1)($ electrolyte $)$ & 0.69 (slightly paramagnetic) $)$ & colorless & 90.9 \\
\hline $\mathrm{HgBr}_{2}(\mathrm{P} . \mathrm{HCl})_{2}$ & $100-120$ & $103.6(1: 1)$ (electrolyte) & 0.70 (slightly paramagnetic) & light greenish & 81.7 \\
\hline
\end{tabular}

Table 2. Elemental analyses of metal-P.HCl complexes

\begin{tabular}{|l|l|c|c|c|}
\hline Complex & Molecular Formula (Mol wt: g/mol) & \%C exp. (Theor.) & \%H exp. (Theor.) & \%N exp. (Theor.) \\
\hline $\mathrm{ZnBr}_{2}(\mathrm{PHCl})_{2}$ & {$\left[\mathrm{ZnBr}\left(\mathrm{C}_{17} \mathrm{H}_{21} \mathrm{Cl}_{2} \mathrm{~N}_{2} \mathrm{~S}\right)_{2}\right] \mathrm{Br}(867.03)$} & $46.80(47.10)$ & $4.85(4.88)$ & $6.12(6.13)$ \\
\hline $\mathrm{CdBr}_{2}(\mathrm{PHCl})_{2}$ & {$\left[\mathrm{CdBr}\left(\mathrm{C}_{17} \mathrm{H}_{21} \mathrm{Cl}_{2} \mathrm{~N}_{2} \mathrm{~S}\right)_{2}\right] \mathrm{Br}(914.05)$} & $44.67(44.68)$ & $4.60(4.63)$ & $6.12(6.13)$ \\
\hline $\mathrm{CdI}_{2}\left(\mathrm{PHCl}_{2} \mathrm{H}_{2} \mathrm{O}\right.$ & {$\left[\mathrm{CdI}\left(\mathrm{C}_{17} \mathrm{H}_{21} \mathrm{Cl}_{2} \mathrm{~N}_{2} \mathrm{~S}\right)_{2}\right] \mathrm{I} \cdot \mathrm{H}_{2} \mathrm{O}(1020.3)$} & $39.40(39.79)$ & $4.01(4.31)$ & $5.43(5.45)$ \\
\hline $\mathrm{HgBr}_{2}(\mathrm{PHCl})_{2}$ & {$\left[\mathrm{HgBr}\left(\mathrm{C}_{17} \mathrm{H}_{21} \mathrm{Cl}_{2} \mathrm{~N}_{2} \mathrm{~S}\right)_{2}\right] \mathrm{Br}(1008.1)$} & $40.54(40.75)$ & $4.23(4.22)$ & $5.67(5.59)$ \\
\hline
\end{tabular}

Table 3. UV-Visible spectral data of $\mathrm{P} . \mathrm{HCl}$ and its metal complexes

\begin{tabular}{|c|c|c|c|}
\hline Complex/Ligand & $\lambda_{\max }(\mathrm{nm})$ & Molar absorptivity $(\varepsilon)\left(10^{4}, \mathrm{M}^{-1} \mathrm{~cm}^{-1}\right)$ & Transition \\
\hline \multirow[b]{2}{*}{ P.HCl } & 259.0 & 1.42 & \multirow[b]{2}{*}{$\pi \rightarrow \pi^{*}$} \\
\hline & 306.5 & 0.22 & \\
\hline \multirow{2}{*}{$\mathrm{ZnBr}_{2}(\mathrm{P} . \mathrm{HCl})_{2}$} & 258.0 & 3.83 & \multirow{2}{*}{$\pi \rightarrow \pi^{*}$} \\
\hline & 306.5 & 0.58 & \\
\hline \multirow{2}{*}{$\mathrm{CdI}_{2}(\mathrm{P} . \mathrm{HCl})_{2} \cdot \mathrm{H}_{2} \mathrm{O}$} & 258.0 & 4.54 & \multirow{2}{*}{$\pi \rightarrow \pi^{*}$} \\
\hline & 306.5 & 0.62 & \\
\hline \multirow{2}{*}{$\mathrm{CdBr}_{2}(\mathrm{P} . \mathrm{HCl})_{2}$} & 259.0 & 4.11 & \multirow{2}{*}{$\pi \rightarrow \pi^{*}$} \\
\hline & 306.5 & 0.68 & \\
\hline \multirow{2}{*}{$\mathrm{HgBr}_{2}(\mathrm{P} \cdot \mathrm{HCl})_{2}$. } & 258.0 & 4.54 & \multirow{2}{*}{$\pi \rightarrow \pi^{*}$} \\
\hline & 306.5 & 0.63 & \\
\hline
\end{tabular}


Table 4. Important IR absorptions of $\mathrm{P} . \mathrm{HCl}$ and its metal complexes

\begin{tabular}{|c|c|c|c|c|}
\hline Complex/ligand & $\begin{array}{c}\text { Absorption of } \\
\left(\mathrm{R}_{3} \mathrm{NH}^{+}\right)\left(\mathrm{cm}^{-1}\right)\end{array}$ & $\begin{array}{c}\text { Absorption of } \\
\left(>\mathrm{N}-\mathrm{R}^{1}\right)\left(\mathrm{cm}^{-1}\right)\end{array}$ & $\begin{array}{c}\text { Absorption of } \\
(\mathrm{C}-\mathrm{S}-\mathrm{C})\left(\mathrm{cm}^{-1}\right)\end{array}$ & $\begin{array}{c}\text { Absorption of } \\
(\mathrm{C}-\mathrm{N})\left(\mathrm{cm}^{-1}\right)\end{array}$ \\
\hline $\mathrm{P} . \mathrm{HCl}$ Ligand & $2689-2515$ & $3053-2853$ & $771-748$ & $1038 \& 972$ \\
\hline $\mathrm{ZnBr}_{2}(\mathrm{P} . \mathrm{HCl})_{2}$ & $2764-2650$ & $3054-2862$ & 760 & $1036 \& 972$ \\
\hline $\mathrm{CdBr}_{2}(\mathrm{P} \cdot \mathrm{HCl})_{2}$ & $2837-2639$ & $3019-2837$ & 758 & $1035 \& 973$ \\
\hline $\mathrm{CdI}_{2}(\mathrm{P} . \mathrm{HCl})_{2} \cdot \mathrm{H}_{2} \mathrm{O}^{*}$ & $3067-2652$ & $3067-2789$ & 760 & $1035 \& 970$ \\
\hline $\mathrm{HgBr}_{2}(\mathrm{P} \cdot \mathrm{HCl})_{2}$ & $2716-2608$ & $3069-2813$ & 759 & $1036 \& 972$ \\
\hline
\end{tabular}

* indicates $\mathrm{OH}$ absorption band at $3225-3400 \mathrm{~cm}^{-1}$

Table 5. Proton-NMR data of $\mathrm{P} . \mathrm{HCl}$ and its metal complexes*

\begin{tabular}{|c|c|}
\hline Ligand/Complex & $\delta$ Chemical shift (multiplicity, protons) \\
\hline $\mathrm{P} . \mathrm{HCl}$ & $2.0(\mathrm{~m}, 2 \mathrm{H}), 2.68(\mathrm{~s}, 6 \mathrm{H}), 3.13-3.15(\mathrm{t}, 2 \mathrm{H}), 3.94-3.98(\mathrm{t}, 2 \mathrm{H}), 7.1-7.2(\mathrm{~m}, 7 \mathrm{H}), 10.80(\mathrm{br} . \mathrm{s}, 1 \mathrm{H})$. \\
\hline $\mathrm{ZnBr}_{2}(\mathrm{P} . \mathrm{HCl})_{2}$ & $2.02-2.07(\mathrm{~m}, 2 \mathrm{H}), 2.73(\mathrm{~s}, 6 \mathrm{H}), 3.12-3.17(\mathrm{t}, 2 \mathrm{H}), 3.93-3.97(\mathrm{t}, 2 \mathrm{H}), 7.09-7.21(\mathrm{~m}, 7 \mathrm{H}), 9.39(\mathrm{br} . \mathrm{s}, 1 \mathrm{H})$. \\
\hline $\mathrm{CdBr}_{2}(\mathrm{P} . \mathrm{HCl})_{2}$ & $2.05-2.08(\mathrm{~m}, 2 \mathrm{H}), 2.74(\mathrm{~s}, 6 \mathrm{H}), 3.12-3.18(\mathrm{t}, 2 \mathrm{H}), 3.93-3.98(\mathrm{t}, 2 \mathrm{H}), 6.98-7.21(\mathrm{~m}, 7 \mathrm{H}) 9.39(\mathrm{br} . \mathrm{s}, 1 \mathrm{H})$. \\
\hline $\mathrm{CdI}_{2}(\mathrm{P} . \mathrm{HCl})_{2} . \mathrm{H}_{2} \mathrm{O}$ & $2.01-2.06(\mathrm{~m}, 2 \mathrm{H}), 2.80(\mathrm{~s}, 6 \mathrm{H}), 3.12-3.17(\mathrm{t}, 2 \mathrm{H}), 3.93-3.97(\mathrm{t}, 2 \mathrm{H}), 6.98-7.24(\mathrm{~m}, 7 \mathrm{H}), 9.27(\mathrm{br} . \mathrm{s}, 1 \mathrm{H})$ \\
\hline $\mathrm{HgBr}_{2}(\mathrm{P} . \mathrm{HCl})_{2}$ & $2.02-2.07(\mathrm{~m}, 2 \mathrm{H}), 2.73(\mathrm{~s}, 6 \mathrm{H}), 3.12-3.17(\mathrm{t}, 2 \mathrm{H}), 3.93-3.98(\mathrm{t}, 2 \mathrm{H}), 7.09-7.21(\mathrm{~m}, 7 \mathrm{H}), 9.42(\mathrm{br} . \mathrm{s}, 1 \mathrm{H})$. \\
\hline
\end{tabular}

* In DMSO-d 6

All complexes behave as 1:1 electrolytes as shown by their molar conductance data, which are presented in Table 1. The overall magnetic data of the complexes show the low spin nature of the $\mathrm{d}^{10}$ metal ions with two of them, $\mathrm{Cd}(\mathrm{II}) \mathrm{I}_{2}$ and $\mathrm{Hg}(\mathrm{II}) \mathrm{Br}_{2}$, deviating slightly which probably can be attributed to the presence of paramagnetic impurities[20]. Elemental analysis results listed in Table 2 show that the theoretical values for $\mathrm{C}, \mathrm{H}, \mathrm{N}$ are in agreement with the experimental ones. The complexes contain one metal center and two promazine hydrochlorides as principal ligands. The other ligands include bromide or iodide ions. Additionally, $\mathrm{CdI}_{2}$ complex contains one $\mathrm{H}_{2} \mathrm{O}$ molecule as the water of hydration.

The UV-Visible spectral data of the ligand (P.HCl) and its metal-complexes are presented in Table 3. The broad bands observed in the UV region of $255-310 \mathrm{~nm}$ in the spectra of all complexes can be attributed to the intraligand transitions[15-23]. The molar absorptivities $(\varepsilon)$ of the complexes falling in the range of $5.8 \times 10^{3}$ to $4.55 \times 10^{4} \mathrm{M}^{-1}$ $\mathrm{cm}^{-1}$, are higher than those of the ligand in the free state which are $2.2 \times 10^{3} \mathrm{M}^{-1} \mathrm{~cm}^{-1}$ and $1.42 \times 10^{4} \mathrm{M}^{-1} \mathrm{~cm}^{-1}$ at $306.5 \mathrm{~nm}$ and $259 \mathrm{~nm}$, respectively. The increased molar absorptivities can be attributed to the transitions of $\pi-\pi^{*}$ type (hypsochromic shift). This may be taken as an indirect evidence for involvement of the $\mathrm{N}$ atoms in the coordination process, confirming the complex formation between metal and ligand[15-23].

Infrared spectral data of P.HCl ligand and its complexes are presented in Table 4. In the free P.HCl ligand spectrum, a strong band observed at $\sim 2500-2700 \mathrm{~cm}^{-1}$ region is attributable to the interactions of a halide ion with the exocyclic quarternary ammonium ion $\left(\mathrm{R}_{3} \mathrm{NH}\right)^{+}$. In the spectra of $\mathrm{Zn}(\mathrm{II}), \mathrm{Cd}(\mathrm{II})$ amd $\mathrm{Hg}$ (II) complexes, this band shifts to a higher wave number with diminished intensity indicating weakening of the hydrogen bonding between the nitrogen atom of the exocyclic quarternary ammonium ion $\left(\mathrm{R}_{3} \mathrm{NH}\right)^{+}$ and halide ions.[12-15,21,22]. A band observed in the $3000-2800 \mathrm{~cm}^{-1}$ region in the spectrum of $\mathrm{P} . \mathrm{HCl}$ may be assigned to the heterocyclic nitrogen atom carrying an alkyl amine side chain[21,22]. This band of $\mathrm{P} . \mathrm{HCl}$ shows a shift upon complexation suggesting its coordination to the metal(II) center [10-14]. The broad absorption band $\sim 3200-3400 \mathrm{~cm}^{-1}$ supports the $\mathrm{H}$-bonded $\mathrm{OH}$ interactions of the water of hydration in $\mathrm{CdI}_{2}$ complex. In the free ligand, the vibrations of heterocyclic $v(\mathrm{C}-\mathrm{S}-\mathrm{C})$ are different from their $\mathrm{Cd}(\mathrm{II})$ and $\mathrm{Hg}(\mathrm{II})$ complexes, due to the coordination of the heterocyclic $\mathrm{S}$ atom to the metal center as compared to the $\mathrm{Zn}(\mathrm{II})$ center which is bonded to the heterocyclic $\mathrm{N}$ atom $[12,15,22]$.

The ${ }^{1} \mathrm{H}$ NMR data for the ligand, $\mathrm{P} . \mathrm{HCl}$, and its complexes are presented in Table 5. A comparison of the nature of important peaks/multiplets and their chemical shifts of the spectra reveals that the resonance signals of the uncomplexed ligand have experienced small shifts upon coordination to metal ions. The above spectral changes indicate the involvement of its exocyclic $\mathrm{N}$ atom and a heterocyclic $\mathrm{N}$ or $\mathrm{S}$ atom as donor coordination sites. The broad singlet peak in the free ligand $(\delta 10.80)$ shifted upfield in the complexes is attributed to the complex formation via intramolecular H-bonding between exocyclic $\left(\mathrm{R}_{3} \mathrm{NH}\right)^{+}$and $\mathrm{Cl}^{-}$of the $\mathrm{N}_{2} \mathrm{MX}_{3}$ or $\mathrm{S}_{2} \mathrm{MX}_{3}$ moiety of the complex[12,15,24].

Crystals of sufficient quality required to permit $\mathrm{x}$-ray crystallographic analysis of the complexes could not be grown. Based on the discussed analytical data, tentative square pyramidal structures have been proposed for all the complexes (Figs. 3A and 3B.). Similar structures have been reported for other phenothiazine-transition metal complexes[12-15,24]. The $\mathrm{Zn}(\mathrm{II}), \mathrm{Cd}(\mathrm{II})$ and $\mathrm{Hg}(\mathrm{II})$ complexes have the general ionic formula $\left[\mathrm{MX}(\mathrm{P} . \mathrm{HCl})_{2}\right] \mathrm{X}$, where $\mathrm{M}=$ metal(II) center with $\mathrm{d}^{10}$ configuration and $\mathrm{X}=\mathrm{Br}^{-}$or $\mathrm{I}^{-}$. According to the valence bond theory, the five-coordinate $\mathrm{Zn}(\mathrm{II}), \mathrm{Cd}(\mathrm{II})$ and $\mathrm{Hg}(\mathrm{II})$ centers of the complexes involve $\mathrm{sp}^{3} \mathrm{~d}$ hybridized atomic orbitals. In the complexes, each central metal ion forms a square planar base unit containing two M-N or M-S bonds with heterocyclic N/S atoms of two promazine hydrochloride ligands, two $\mathrm{M}-\mathrm{Cl}$ bonds with 
each chloride ion which in turn is hydrogen-bonded to the nitrogen atom of the exocyclic quarternary ammonium ion of the ligand, and one axial M-Br or M-I bond within the inner coordination sphere. The heterocyclic $\mathrm{N}$ atom as the coordination site for a small/hard $\mathrm{Zn}(\mathrm{II})$ ion and the heterocyclic $\mathrm{S}$ atom as the site for a relatively larger/softer $\mathrm{Cd}(\mathrm{II})$ or $\mathrm{Hg}(\mathrm{II})$ ion in the complexes can be justified based on the Pearson's HSAB interactions. In coordination, the hard acid $\mathrm{Zn}(\mathrm{II})$, prefers a hard $\mathrm{N}$ end while the softer acid, $\mathrm{Cd}(\mathrm{II})$ or $\mathrm{Hg}(\mathrm{II})$, prefers to coordinate with a softer $\mathrm{S}$ site of the ligand. Each complex has a distorted square pyramidal geometry around the metal(II) center and the distortion can be attributed to the chelating effect of the bidentate $\mathrm{P} . \mathrm{HCl}$ ligand. The scorpion tail like N-alkylamino (R) group with its flexible bending mode is well suited for this kind of intramolecular H-bonding in the ligands, NAPTZs[11-19]. The structures (Figs. 3A and 3B) are supported by the lowspin nature of the complexes.

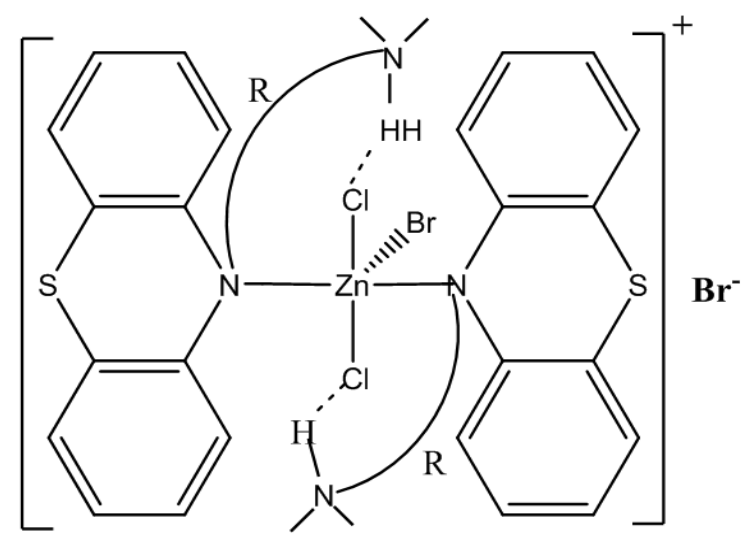

Here for the promazine (P) ligand: $\mathrm{R}=\left(\mathrm{CH}_{2}\right)_{3} \mathrm{~N}\left(\mathrm{CH}_{3}\right)_{2}$;

Figure 3A. Proposed structure of $\left[\mathrm{ZnBr}(\mathrm{P} . \mathrm{HCl})_{2}\right] \mathrm{Br} . \mathrm{R}=\left(\mathrm{CH}_{2}\right)_{3} \mathrm{~N}\left(\mathrm{CH}_{3}\right)_{2}$

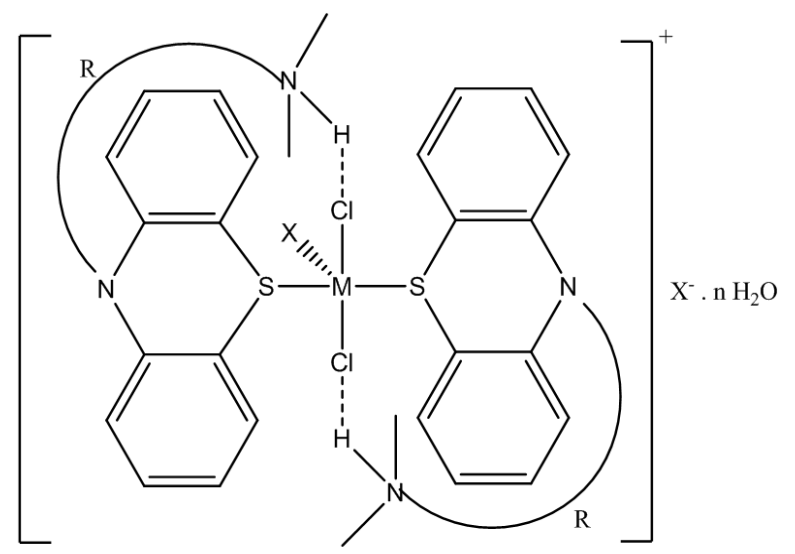

Here for the promazine (P) ligand: $\mathrm{R}=\left(\mathrm{CH}_{2}\right)_{3} \mathrm{~N}\left(\mathrm{CH}_{3}\right)_{2} ; \mathrm{X}^{-}$is $\mathrm{Br}^{-}$or $\mathrm{I}^{-}$and $\mathrm{n}=0$ or 1

Figure 3B. Proposed general molecular structure for the Complexes, $\left[\mathrm{CdBr}(\mathrm{P} . \mathrm{HCl})_{2}\right] \mathrm{Br},\left[\mathrm{CdI}(\mathrm{P} . \mathrm{HCl})_{2}\right] \mathrm{I} . \mathrm{H}_{2} \mathrm{O}$ and $\left[\mathrm{HgBr}(\mathrm{P} . \mathrm{HCl})_{2}\right] \mathrm{Br}$

\section{Conclusions}

Transition metal-promazine hydrochloride complexes have been prepared and characterized based on their spectroscopic data. A distorted square-pyramidal structure has been proposed for the new complexes. The future work would be on the determination of in vitro antioxidant and free radical scavenging activities of these complexes using standard assays.

\section{ACKNOWLEDGEMENTS}

The authors are grateful to the Western Illinois University Research Council and the US National Cancer Institute-NIH (AREA grant \# 1R15 CA115404-01) for support.

\section{REFERENCES}

[1] Snyder, S.H., 1976, Amer. J. Psychiatry, 133, 197

[2] O. Bratfos and J.O. Haug, Acta Psychiat, Scand., 60, 1, 1979

[3] A.R. Katritzky and A.J. Boulton (Eds.), Advances in heterocyclic Chemistry, Academic press, New York, 1968

[4] Keshavan, B., and Seetharamappa, J., 1987, Polyhedron, 6(3), 465

[5] Keshavan, B., and Seetharamappa, J., 1986, Synth. React. Met.-Org. Chem., 16(7), 979

[6] Keshavan, B., and Janardhan, R., 1987, Ind. J. Chem., 26A, 975

[7] Keshavan, B., and Janardhan, R., 1987, Ind. J. Chem., 25A, 1054

[8] Sanke Gowda, H., and Jayarama., 1981, J. Inorg. Nucl. Chem., 43(10), 2329

[9] Kroener, R., Heeg, M. J., and Deutsch, E., 1988, Inorg. Chem., 27, 558

[10] Made Gowda, N.M., and Phyu, H.P., 1992, Ttransition Met. Chem., 17, 467; H.P. Phyu, M.S. Thesis, Western Illinois University, Macomb, USA, May, 1991

[11] Made Gowda, N.M., Phyu, H.P., and Ackerson, B.E., 1993, Transition Met. Chem., 18, 64

[12] Made Gowda, N.M., Kyi, M.M., and Zhang, L., 1993, Transition Met.Chem., 18, 518; M.M. Kyi, MS. Thesis, Western Illinois University, Macomb, USA, December 1991; Made Gowda, N.M., and Zhang, L., 1994, Synth. React. Inorg. Met-Org. Chem., 24(5), 831; L. Zhang, M.S. Thesis, Western Illinois University, Macomb, USA, May, 1992

[13] Made Gowda, N.M., Ackerson, B.E., Morland, M., and Rangappa, K.S., 1993, Transition Met. Chem., 18, 271

[14] Made Gowda, N.M., Pacquette, H.L., Kim, D.H., and Jayaram, B., 1996, J. Mol. Struct., 382 ,129; Made Gowda, N.M., Vallabhaneni, R.K., Gajula, I., and AAFZAL, D., 1996, Synth. React Inorg. Met-Org. Chem, 26(4), 685

[15] Made Gowda, N.M., Lawrence Pacquette, H., Kim 
Doo-Hyung, Jayaram, Beby, 1996, J. Mol. Struct, 382, 129-135; Made Gowda, N.M., Rouch, W.D., and Viet, A.Q., 1993, The Chemistry of copper and Zinc Triads., Royal Society of Chemistry, Cambridge, U.K, 117-120

[16] Made Gowda, N.M., Vallabhaneni, R.K., Gajula, I., Ananda, S., 1997, J. Mol. Struct., 407, 125-130

[17] Chaitanya Lakshmi G., Ananda S., and Made Gowda N.M., 2011, Synthesis, characterization, and antioxidant activity evaluation of pyridoxine and its transition metal complexes. Synthesis and Reactivity in Inorganic, Metal-Organic and Nano-Metal Chemistry, 41, 1-12

[18] Chaitanya Lakshmi G., Ananda S., and Made Gowda N.M., 2009, Synthesis, Characterization and Antioxidant Activity of Zinc(II) and Ruthenium(III) Pyridoxine Complexes., Synthesis and Reactivity in Inorganic, Metal-Organic and Nano-Metal Chemistry, 39(8), 434-440
[19] Chaitanya Lakshmi G., Ananda S., and Made Gowda N.M., 2010, Synthesis of Iron-Pyridoxine Complex by Solvothermal Process, Its Structural Characterization and Antioxidant Activity Evaluation., J. Chem. Chemical. Engg, 4(12), 33-37

[20] J.M. Huheey, E.A. Keiter and R.L. Keiter, Inorganic Chemistry; Principles of Structures and Reactivity, $4^{\text {th }}$ ed., Harper Collins College Publishers, 1993

[21] L.J. Bellemy, The Infrared Spectra of Complex Molecules, Methuen, London, p.355, 1964

[22] K. Nkamoto, Infrared Spectra of Inorganic and Coordination Compounds, Wiley Interscience, New York, 1970

[23] D.A. Skoog and D.M. West, Principles of Instrumental Analysis, Saunders College, P.A, 1980, 171-173

[24] Jayarama, Thimmaiah, K.N., and D'Souza, M.V., 1985, J. Indian Chem. Soc., 62, 418 